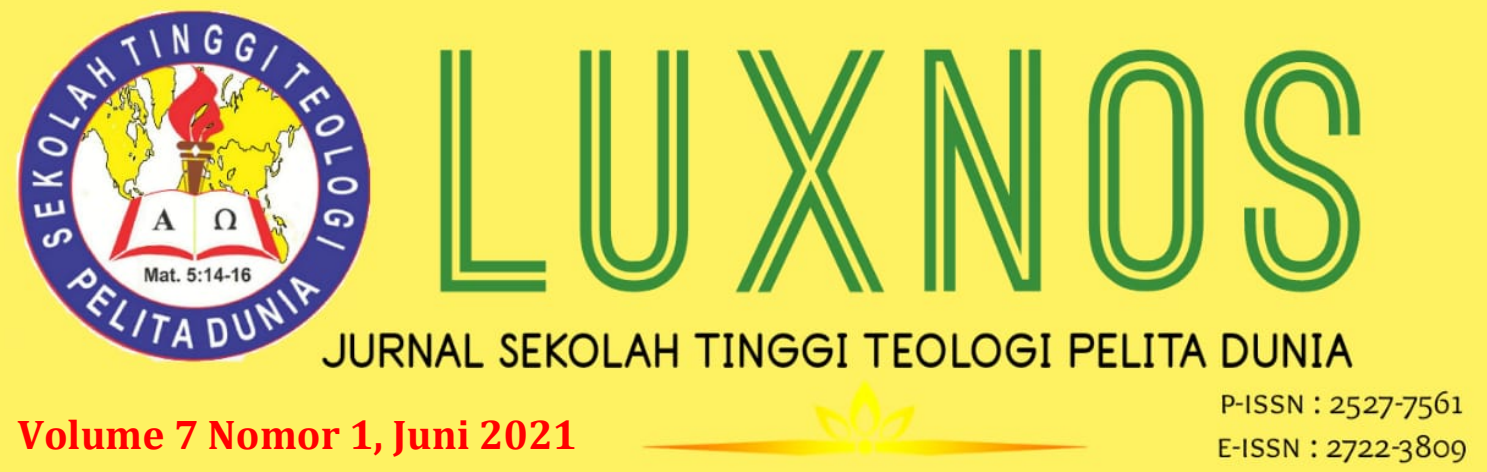

\title{
Pendidikan Agama Kristen dalam Keluarga: Upaya Membangun Spiritualitas Remaja Generasi Z
}

\author{
Yunardi Kristian Zega \\ Universitas Kristen Indonesia, Jakarta \\ yunardichristian@gmail.com
}

\begin{abstract}
The implementation of Christian religious education in the family is one of God's commands for all of His people, so that every future generation will still know God with the correct understanding of faith (Deu. 6: 6-9). The existence of Christian religious education in the family that is carried out properly, will produce children who grow up with a good spirituality of life (Pro. 22: 6). However, what is happening at this time is that there are more and more Christian children, especially teenagers who are starting to live by shedding their identity as God's people. This is due to the influence of changing times and also parents who do not understand how to build their children's spirituality according to their needs in the present, so that these teenagers do not believe in the beliefs of their own religion. Therefore, in this article, the author uses the library research method to provide solutions to these problems. With the aim is to provide an overview and concept to parents about the implementation of Christian religious education in the family to build the spirituality of generation $\mathrm{Z}$ adolescents.
\end{abstract}

\section{Keywords: Family; Christian education; Generation Z Youth; Spirituality}

\begin{abstract}
Abstrak : Pelaksanaan pendidikan agama Kristen dalam keluarga merupakan salah satu perintah Allah bagi semua umat-Nya, supaya setiap generasi yang akan datang tetap mengenal Allah dengan pemahaman iman yang benar (Ul. 6:6-9). Adanya pendidikan agama Kristen dalam keluarga yang dilaksanakan dengan baik, akan menghasilkan anakanak yang bertumbuh dengan spiritualitas hidup yang baik pula (Ams. 22:6). Akan tetapi yang terjadi pada saat ini, justru semakin banyak anak-anak Kristen, khususnya di kalangan remaja yang mulai hidup dengan menanggalkan identitasnya sebagai umat Allah. Hal ini disebabkan oleh pengaruh perubahan zaman dan juga kurangnya pemahaman orang tua tentang bagaimana cara membangun spiritualitas anak-anaknya yang sesuai dengan kebutuhan mereka dimasa sekarang, sehingga anak-anak remaja tersebut tidak mempercayai keyakinan dari agamanya sendiri. Oleh karena itu, dalam artikel ini, penulis menggunakan metode kajian pustaka untuk memberikan solusi dalam permasalahan tersebut. Dengan tujuan ialah untuk memberikan gambaran dan konsep terhadap orang tua tentang pentingnya pelaksanaan pendidikan agama Kristen dalam keluarga untuk membangun spiritualitas remaja generasi $\mathrm{Z}$.
\end{abstract}

Kata Kunci: Keluarga; Pendidikan Agama Kristen; Remaja Generasi Z; Spiritualitas 


\section{JURNAL LUXNOS \\ Volume 7 Nomor 1, Juni 2021}

\section{Pendahuluan}

Perkembangan zaman dan teknologi sekarang ini, sangat signifikan dalam mempengaruhi segala aspek kehidupan manusia, baik yang berdampak secara positif maupun yang berdampak secara negatif. Salah satu dampak negatif yang dapat dirasakan yaitu semakin meningkatnya kasus perilaku yang tidak terkontrol dikalangan remaja. Remaja adalah anak yang sedang mencari indentitas dirinya, sehingga sangat rentan terhadap pengaruh negatif dari lingkungan sekitarnya. ${ }^{1}$ Dengan demikian, hal ini menjadi sebuah tantangan bagi para orang tua masa kini dalam mendidik remaja generasi Z, dimana anak-anak tersebut dilahirkan dan bertumbuh dikelilingi oleh teknologi-teknologi canggih yang telah banyak mempengaruhi pola berpikirnya.

Paul Gunadi mengatakan, adapun dampak negatif dari perkembangan teknologi dikalangan remaja antara lain: Pertama, kemajuan teknologi membuat anak menjadi cepat puas dengan apa yang diperolehnya dari internet. Bila keadaan ini terus berlanjut, maka anak akan bertumbuh menjadi generasi yang cenderung berpikir dangkal. Kedua, kemajuan teknologi membawa banyak kemudahan, sehingga membentuk karakter anak yang tidak mampu dalam menghadapi kesulitan. Ketiga, kemajuan teknologi mempercepat banyak pekerjaan. Hal ini dapat membentuk karakter anak menjadi lemah dalam mengontrol kesabarannya sehingga anak cenderung ingin cepat mendapatkan apa yang diinginkannya. Keempat, kemajuan teknologi berpotensi membuat anak enggan berelasi dalam dunia nyata, dikarenakan kebanyakan mereka lebih menyukai bermain sendiri dengan barang-barang teknologi yang dimilikinya. ${ }^{2}$ Selain itu, dampak negatif yang ditimbulkan dengan adanya kemajuan teknologi di kalangan remaja Kristen saat ini yaitu banyaknya anak-anak dikalangan remaja Kristen mengalami kemunduran rohani. Hal ini dapat dilihat dari kehidupan remaja Kristen masa kini yang lebih menyukai untuk menghabiskan waktu dengan bermain smartphone daripada untuk beribadah dan bersekutu kepada Tuhan, ${ }^{3}$ serta kemunduran rohani tersebut juga ditandai dengan mulai banyaknya remaja Kristen yang meninggalkan gereja karena cenderung ingin menyenangkan dirinya sendiri. ${ }^{4}$

Berdasarkan penjelasan di atas, kehadiran perkembangan teknologi di tengahtengah masyarakat, berdampak pula pada pertumbuhan Spiritualitas dikalangan remaja

1 Primasari, Dwi Ammelia Galuh, Dencik Dencik, and M. Imansyah, "Pendidikan Karakter Bagi Generasi Masa Kini," Prosiding Seminar Nasional Program Pascasarjana Universitas PGRI Palembang 12, no. 112019$): \quad 1100-1118, \quad$ https://jurnal.univpgripalembang.ac.id/index.php/Prosidingpps/article/view/2672.

2 Pdt. Dr. Paul Gunadi, "Anak dan Kemajuan Teknologi," Telaga, last modified 2016, diakses Agustus 12, 2020, https://telaga.org/audio/anak_dan_kemajuan_teknologi.

3 Susi Susanti, "Gaya Hidup Pemuda Kristen Terhadap Perkembangan Teknologi (Media Sosial)," OSF, 2020, https://doi.org/10.31219/osf.io/zrt6u.

4 Puji Astuti, "Bimas Kristen Ungkap 50\% Generasi Milenial Kristen Tinggalkan Gereja, Ini Data Risetnya!," Jawaban. com, last modified 2019, diakses Mei 22, 2020, https://www. jawaban. c om/read/article/id/2019/07/10/91/190710154206/bimas_kristen_ungkap_50generasi milenial_kristen_tinggalkan_gerejaini_data_risetnya. 
Kristen sekarang ini. Namun semua itu tidak akan berdampak buruk, apabila remaja Kristen mendapat pendidikan yang tepat. Untuk itu, salah satu tempat yang paling tepat untuk membangun Spiritualitas remaja Kristen (generasi Z) adalah melalui PAK dalam keluarga yang dilaksanakan dengan baik.

\section{Metode Penelitian}

Dalam penulisan artikel ini, penulis menggunakan metode studi pustaka. Di mana penulis memberikan solusi dari permasalahan yang diangkat dengan mengumpulkan berbagai teori dan informasi dari bahan kepustakaan, seperti buku, kamus, jurnal, Alkitab, tafsiran, media online, dan sumber-sumber lainnya. Kemudian, sumber-sumber tersebut adalah sumber yang dapat dipertanggungjawabkan secara akademik. Selain itu, bahan-bahan yang digunakan dari sumber pustaka tersebut terdiri dari konsep, pendapat, dan gagasan yang telah dipilih oleh penulis berdasarkan kesesuaian terhadap pembahasan.

\section{Hasil dan Pembahasan}

\section{Pendidikan Agama Kristen dalam Keluarga (PAK Keluarga)}

Pendidikan agama Kristen (PAK) adalah sebuah pelayanan dalam bidang pendidikan yang memberikan fondasi pengajaran iman Kristen kepada peserta didik melalui keluarga, gereja, dan sekolah. ${ }^{5}$ Adapun tujuan PAK menurut pandangan para ahli yang diringkas dari artikel jurnal yang ditulis oleh Talizaro Tafanao mengenai tujuan PAK, antara lain: 1) Hieronimus menjelaskan, PAK bertujuan untuk mendidik jiwa menjadi bait Tuhan. 2) Agustinus menjelaskan, PAK bertujuan untuk mengajarkan hidup yang penuh sukacita bersama Allah. 3) Martin Luther mengatakan, PAK bertujuan untuk mengajarkan jemaat agar belajar menyadari dosa-dosanya dan memiliki sukacita dalam Yesus Kristus karena telah dimerdekakan dari hukuman akibat dosanya. 4) John Calvin mengatakan, PAK bertujuan untuk mendidik jemaat gereja supaya terlibat dalam penelaahan Alkitab secara cerdas dengan tuntunan dari Roh kudus, terlibat dalam pelayanan gereja, dan diperlengkapi untuk mengabdikan diri kepada Yesus Kristus dalam kehidupannya serta senantiasa bersyukur karena telah ditebus dosanya melalui pengorbanan Yesus Kristus. ${ }^{6}$

Berdasarkan penjelasan di atas, dapat disimpulkan bahwa PAK merupakan pelayanan yang memberikan pengajaran berlandaskan ajaran Alkitab kepada setiap peserta didik. Dengan tujuan, agar peserta didik yang diajar dapat memiliki

\footnotetext{
${ }^{5}$ Desi Sianipar et al., "Pelatihan Penyusunan Kurikulum Pendidikan Agama Kristen Remaja di HKBP Jatisampurna Bekasi," JURNAL ComunitÃ Servizio: Jurnal Terkait Kegiatan Pengabdian kepada Masyarakat, terkhusus bidang Teknologi, Kewirausahaan dan Sosial Kemasyarakatan 2, no. 2 (November 2, 2020): 447-457, http://ejournal.uki.ac.id/index.php/cs/article/view/1964.

6 Talizaro Tafonao, "Peran Pendidikan Agama Kristen Dalam Keluarga Terhadap Prilaku Anak," Edudikara: Jurnal Pendidikan Dan Pembelajaran Vol.3, no. No.2 (2018): 129-131.
} 


\section{JURNAL LUXNOS \\ Volume 7 Nomor 1, Juni 2021}

pertumbuhan spiritualitas yang baik sehingga dapat menunjukkan karakter hidup yang sesuai dengan ajaran iman Kristen. Dalam pelaksanaannya PAK dapat dilaksanakan di gereja, sekolah, dan keluarga. Namun, dalam penulisan artikel ini, penulis fokus pada PAK dalam keluarga.

Keluarga Kristen merupakan sebuah tempat pendidikan yang pertama dan utama, khususnya dalam menumbuhkan spiritualitas seseorang agar hidup sejalan dengan ajaran iman Kristen. ${ }^{7}$ Keluarga Kristen adalah pemberian Tuhan yang bernilai karena keluarga Kristen mempunyai peran yang sangat penting melebihi tugas gereja dan sekolah dalam mendidik anak-anak. ${ }^{8}$ Oleh karena itu, keluarga Kristen tidak boleh menyerahkan pelaksanaan PAK hanya kepada gereja dan sekolah saja, melainkan orang tua harus lebih berperan aktif memberikan pendidikan kepada anak-anaknya, melalui PAK dalam Keluarga.

Di dalam keluarga Kristen, Allah telah menugaskan para orang tua agar bertanggungjawab memberikan pengajaran bagi anak-anaknya melalui PAK keluarga (Ul. 6:6-7). PAK keluarga dibangun atas dasar iman dan kepercayaan kepada Allah dalam Yesus Kristus. Tujuan PAK dalam keluarga yaitu untuk mewujudkan keluarga Kristen yang mampu mengimplementasikan imannya dalam kehidupan sehari-hari dan mewariskan iman tersebut secara turun-temurun kepada generasi berikutnya. ${ }^{9}$ Adapun beberapa ayat Alkitab yang dapat menjadi landasan PAK keluarga dalam mendidik generasi muda, antara lain; Alkitab Perjanjian Lama (PL), Ulangan 6:4-9; Mazmur 127:4; dan Amsal 22:6. Alkitab Perjanjian Baru (PB), Matius 19:14; Efesus 6:4; 1 Timotius 4:12; dan 3 Yoh. 1:4.

\section{Remaja Generasi Z}

Masa remaja merupakan kondisi di mana individu masih berumur belasan tahun dan belum dapat disebut sebagai orang dewasa. Masa remaja berada pada antara usia 11-21 tahun. Remaja diistilahkan sebagai masa puber. Istilah tersebut menunjuk pada masa transisi dari masa anak-anak menuju ke masa dewasa. ${ }^{10}$ Adapun sejumlah sikap dan tindakan yang umumnya sering ditunjukkan oleh individu yang sedang memasuki remaja, antara lain: ${ }^{11}$

- Perasaan gelisah. Kaum remaja mempunyai banyak angan-angan yang ingin diwujudkannya. Namun, remaja masih belum mempunyai kemampuan dalam

\footnotetext{
7 Ruwi Hastuti, “Pendidikan Agama Kristen Dalam Keluarga Sebagai Pusat Bermisi," Jurnal Antusias 2, no. 4 (2013): 48-59.

8 Homrighausen E.G. dan I.H. Enklaar, Pendidikan Agama Kristen (Jakarta: BPK Gunung Mulia, 2012), 128.

9 Paulus Lilik Kristianto, Prinsip dan Praktik Pendidikan Agama Kristen (Yogyakarta: ANDI, 2012), 5.

10 Tri Ermayani, "Pembentukan Karakter Remaja Melalui Keterampilan Hidup," Jurnal Pendidikan Karakter 5, no. 2 (2015): 127-141.

11 Mohammad Ali, Psikologi Remaja Perkembangan Peserta Didik (Jakarta: Bumi Aksara, 2010), 1618.
} 
mewujudkan hal-hal tersebut. Oleh karena angan-angan yang tinggi tersebut dan tidak dapat diimbangi dengan kemampuan yang dimilikinya mengakibatkan remaja diliputi oleh perasaan gelisah.

- Mengalami pertentangan dengan diri sendiri. Remaja adalah individu yang sedang mencari identitas dirinya. Karena itu, remaja sangat ingin melepaskan diri dari ketergantungan dari orang tuanya, namun pada akhirnya remaja takut karena masih merasa belum mampu. Hal tersebut menjadikan remaja sering mengalami pertentangan dengan dirinya sendiri.

- Suka mengkhayal. Remaja memiliki banyak keinginan untuk bertualang, namun semua itu tidak dapat tersalurkan karena sering terkendala oleh biaya. Akibatnya, kebayakan dari remaja sering mencari kepuasan tersebut dengan cara mengkhayal melalui dunia fantasinya.

- Suka berkelompok. Ada banyak larangan yang sering dibuat para orang tua yang justru mematahkan semangat dari para remaja. Pada akhirnya, kebanyakan remaja dalam menanggapi hal tersebut, remaja lebih menyukai berkumpul dengan temanteman sebayanya untuk melakukan kegiatan yang menurut mereka menyenangkan.

- Keinginan mencoba. Masa remaja adalah masa di mana anak memiliki rasa ingin tahu yang tinggi (high curiosty). Rasa ingin tahu yang tinggi ini sering membuat remaja ingin sama seperti orang dewasa, sehingga remaja memiliki keinginan untuk melakukan apa yang sering dilakukan oleh orang-orang dewasa yang ada di sekitarnya. Akibatnya, sering sekali remaja pria mencoba merokok karena melihat orang dewasa laki-laki yang merokok, sedangkan remaja putri sering mencoba memakai kosmetik karna melihat orang-orang dewasa wanita yang memakai kosmetik.

Setiap generasi di zaman yang berbeda, mempunyai tantangan tersendiri dalam mendidik anak-anak remaja tersebut. Untuk itu, ada 5 generasi yang perlu diketahui, antara lain: 1) Generasi baby boomer, yaitu anak yang lahir pada tahun 1946-1964. 2) Generasi X, yaitu anak yang lahir pada pada tahun 1965-1980. 3) Generasi Y, yaitu anak yang lahir pada tahun 1981-1994. 4) Generasi Z, yaitu anak yang lahir pada tahun 19952010. 5) Generasi Alpha, yaitu anak yang lahir pada tahun 2011-2025.12 Jadi dapat dilihat bahwa, anak remaja saat ini sebagian besar masuk dalam kategori yang disebut generasi Z. Generasi Z merupakan generasi terkini yang telah tumbuh menjadi remaja. Remaja generasi $\mathrm{Z}$ dilahirkan dan dibesarkan di era digitalisasi, di mana terdapat banyak teknologi yang canggih, seperti: laptop, smartphone, ipad, MP3 player, internet, dan barang elektronik lainnya yang sudah menjadi bagian dalam kehidupan mereka

12 Herry Mukhlis, "Pahami Remaja Generasi-Z," AF MAGAZINE (Tanggerang, November 2015), http://alfathschoolindonesia.sch.id/wp-content/uploads/2017/03/Pahami-Remaja-Generasi-Z.pdf. 
sejak kecil. ${ }^{13}$ Apabila diamati lebih lanjut, remaja generasi Z mempunyai kemampuan yang sangat baik dalam mengakses informasi melalui media sosial, sehingga remaja generasi $\mathrm{Z}$ mempunyai lebih banyak kesempatan untuk mengembangkan kemampuan dirinya. ${ }^{14}$

Adapun kelebihan dari remaja generasi Z, antara lain: 1) remaja memiliki rasa ingin tahu yang sangat tinggi, sehingga ketika remaja generasi $\mathrm{Z}$ diperhadapkan dengan teknologi canggih, anak tidak perlu untuk diajari dengan susah-payah karena mereka dengan sendirinya akan berusaha untuk menguasai apa yang dibutuhkannya. 2) remaja generasi $\mathrm{Z}$ adalah generasi yang multitasking, di mana mereka dapat terbiasa dengan berbagai aktivitas pada waktu yang bersamaan. Contohnya: remaja dapat membaca, berbicara, dan mendengarkan pada waktu yang bersamaan. Sedangkan nilai minus dari remaja Generasi Z ini, antara lain: 1) mereka tidak sabaran, sehingga dalam menyelesaikan masalah cenderung menyukai cara-cara instan. 2) sebagian remaja generasi $\mathrm{Z}$ kurang terampil berkomunikasi verbal, sehingga kebanyakan dari mereka tidak peduli dengan lingkungan sekitarnya. ${ }^{15}$

Jadi, berdasarkan uraian di atas dapat dilihat bahwa, generasi Z mempunyai konsep berpikir yang berbeda dari generasi-generasi sebelumnya. Di mana perkembangan kemajauan teknologi dan internet telah banyak membentuk pola berpikir mereka. Oleh karena itu, remaja generasi Z memerlukan pendidikan yang tepat, sehingga mereka tidak terjerumus ke dalam berbagai dampak negatif, akibat kemajuan teknologi yang terus berkembang sekarang ini.

\section{PAK Keluarga Membangun Spiritualitas Remaja Generasi Z}

BR. Agung Prihatana menjelaskan ada tiga tanggung jawab dan kewajiban para orang tua dalam memberikan pendidikan kepada anak-anaknya, yaitu: 1) Kewajiban para orang tua dalam mendidik anak bersifat hakiki. Maksudnya bahwa, kewajiban tersebut merupakan konsekuensi kodrati dan adikodrati dari kelahiran seorang anak di dalam keluarga tesebut. 2) Memiliki sifat asali dan utama, di mana hak dan kewajiban orang tua (ayah dan ibu) untuk memberikan cinta kasih dalam membesarkan dan mendidik anak-anaknya. Cinta kasih antara suami istri adalah sumber, jiwa, dan norma pendidikan. Dengan pendidikan begitu, anak akan terbantu untuk mengalami dan menghayati cinta kasih dari Tuhan Sang Pencipta. 3) Orang tua sebagai pendidik yang pertama dan utama, artinya bahwa peran orang tua tidak bisa digantikan oleh siapa pun dalam mendidik anak-anaknya. Kehadiran atau keterlibatan seperti guru dan tenaga pendidik lainnya hanyalah sebagai membantu orang tua saja, namun pendidikan

\footnotetext{
13 Ibid.

14 Ibid.

15 Ibid.
} 


\section{JURNAL LUXNOS \\ Volume 7 Nomor 1, Juni 2021}

utamanya tetap berasal dari para orang tua. ${ }^{16}$ Dengan demikian, orang tua di dalam sebuah keluarga mempunyai peran yang strategis dalam memberikan pendidikan bagi anak-anaknya. Khususnya di dalam keluarga Kristen, di mana orang tua perlu mendidik anak-anaknya supaya memiliki pertumbuhan spiritualitas yang baik, sehingga anakanak tersebut dapat hidup sesuai dengan ajaran iman Kristen.

Usia remaja merupakan usia yang amat potensial dalam perkembangannya. ${ }^{17}$ Oleh karena itu, menanamkan kecerdasan spritual ${ }^{18}$ pada anak usia remaja merupakan waktu yang sangat tepat. Dengan membekali dan meletakkan fondasi ke imanan yang kokoh, menghasilkan remaja yang tidak menjadi angkuh dan melupakan Tuhan akibat pengaruh kemajuan teknologi dan internet yang semakin canggih saat ini. ${ }^{19}$ Untuk itu, adapun PAK dalam keluarga yang perlu untuk diimplementasikan para orang tua dalam membangun spiritualitas remaja generasi $\mathrm{Z}$, antara lain:

Pertama, membangun mezbah keluarga. ${ }^{20}$ Pembinaan rohani harus menjadi tanggung jawab prioritas oleh orang tua dan tidak boleh diserahkan sepenuhnya, baik kepada gereja maupun sekolah. ${ }^{21}$ Dengan demikian, parah orang tua perlu mendirikan mezbah keluarga, di mana semua anggota keluarga perlu bersama-sama untuk menjalin hubungan yang intim dengan Tuhan. Misalnya, orang tua dapat mengajak semua anggota keluarga untuk doa bersama, tiap pagi hari setelah bangun dan di malam hari sebelum tidur. Selain itu, orang tua juga perlu membuat jadwal khusus, di mana semua anggota keluarga dapat berkumpul bersama untuk memuji Tuhan dan saling sharing untuk membahas Firman Tuhan. Dengan kata lain, pembinaan rohani di dalam keluarga harus dilakukan secara sistematis dan berkesinambungan untuk mengajarkan nilai-nilai kristiani, serta sikap, dan keterampilan yang konsisten terhadap setiap anggota keluarga. ${ }^{22}$ Khususnya bagi anak generasi Z, dengan adanya mesbah keluarga yang dilaksanakan dengan baik akan membuat remaja memiliki hubungan yang intim dengan

16 BR. Agung Prihatana, Pendidikan Iman Anak Dalam Keluarga Kawin Campur Beda Agama (Yogyakarta: Kanisius, 2007), 40-41.

17 Ali, Psikologi Remaja Perkembangan Peserta Didik, 10.

18 "Kecerdasan spiritual merupakan kecerdasan jiwa yang bertujuan untuk membantu mengembangkan diri secara utuh dengan menerapkan nilai-nilai positif yang ada di dalam diri orang tersebut. " https://id.wikipedia.org/wiki/Kecerdasan_spiritual.

19 Muhamad Ngafifi, "Kemajuan Teknologi Dan Pola Hidup Manusia Dalam Perspektif Sosial Budaya," Jurnal Pembangunan Pendidikan: Fondasi Dan Aplikasi 2, no. 1 (2014): 43-44.

20 "Mezbah keluarga adalah di mana ada waktu yang dibuat secara khusus oleh seisi rumah untuk bersama-sama (sebagai keluarga) melaksanakan penyembahan kepada Tuhan Sang Pencipta," https://victoriousnews.com/2019/06/18/membangun-mezbah-doa-dalam-keluarga/\#: :text=Inilah yang disebut sebagai mezbah,firman Tuhan dan berdoa bersama.

21 Riana Udurman Sihombing dan Rahel Rati Sarungallo, "Peranan Orang Tua Dalam Mendewasakan Iman Keluarga Kristen," Journal Kerusso 4, no. 1 (Maret 19, 2019): 34-41, http://jurnal.sttii-surabaya.ac.id/index.php/Kerusso/article/view/104.

22 Santy Sahartian, "Pengaruh Pembinaan Rohani Keluarga Terhadap Karakter Pemuda Berdasarkan Kolose 2: 6-10 Di GBAP Surakarta," FIDEI: Jurnal Teologi Sistematika dan Praktika 2, no. 1 (Juni 18, 2019): 20-39, http://www.stt-tawangmangu.ac.id/e-journal/index.php/fidei/article/view/30. 
Tuhan Yesus, tanpa harus terpengaruh oleh teman-teman mereka yang menanggalkan imannya karena ingin mengikuti trend zaman.

Kedua, membuat target capaian dengan menyesuaikan perkembangan spiritualitas remaja generasi $\mathrm{Z}$ berdasarkan tingkat usianya. James W. Fowler melalui penelitiannya menjelaskan remaja awal usia 12-15 tahun, pada usia ini remaja sudah mampu untuk memahami imannya secara lebih rasional. Sedangkan untuk remaja akhir usia 16-18 tahun, remaja seperti ini sudah mampu untuk bertanggung jawab penuh atas iman yang telah dipercayainya, baik untuk dirinya maupun orang lain yang ada di sekitarnya. ${ }^{23}$ Oleh karena itu, para orang tua perlu mempunyai target dalam mendidik anak remajanya, di mana ketika anak sudah berada di usia remaja akhir, para orang tua perlu memastikan bahwa anak-anak remaja mereka sudah mempunyai spiritualitas yang baik, di mana remaja sudah mampu untuk mempertanggungjawabkan iman Kristen yang telah dipercayainya, sehingga mereka dapat bijak dalam menghadapi pengaruh dari perkembangan zaman.

Ketiga, orang tua mempunyai keteladanan yang baik untuk ditiru. Dalam hal ini, remaja generasi $\mathrm{Z}$ mempelajari keteladanan yang baik dan buruk, banyak diterima dari pengalaman di dalam keluarga. ${ }^{24}$ Wijanarko mengatakan, orang tua adalah panutan bagi setiap anaknya. Jika orang tua tidak memiliki keteladanan yang baik, maka anak akan mudah terjerumus ke dalam berbagai pergaulan yang salah. ${ }^{25}$ Oleh karena itu, orang tua tidak cukup hanya dengan memberikan penjelasan yang baik secara intelektual saja terhadap remaja generasi Z, melainkan juga harus dapat mencerminkan contoh teladan seperti yang telah diajarkannya (Titus 2:7). Dengan kata lain, dalam menumbuhkan spiritualitas remaja generasi $\mathrm{Z}$, orang tua tidak hanya menyuruh untuk melakukan seperti apa yang telah diajarkan, melainkan orang tua juga perlu menerapkannya dalam kehidupan sehari-hari mereka agar dapat ditiru.

Keempat, ada waktu untuk memberikan rasa kasih sayang. Di zaman modern sekarang ini, para orang tua baik ayah maupun ibu, sering sekali sibuk dengan pekerjaan mereka masing-masing untuk memenuhi kebutuhan finansial keluarga, ${ }^{26}$ sehingga anak-anak yang dilahirkan pada generasi $\mathrm{Z}$ banyak yang kurang mendapatkan kasih sayang dari orang tuanya. Akibat dari hal tersebut, remaja generasi $\mathrm{Z}$ menjadi lebih nyaman dengan media sosial, daripada ketika bertemu dengan orang tuanya sendiri. Hal tersebut tentu akan mempengaruhi pertumbuhan dari spiritualitas remaja generasi Z. Wijanarko mengatakan, jika anak mendapatkan rasa kasih sayang yang

23 Zega, "Teori Perkembangan Iman Remaja Menurut James W. Fowler Dan Implikasinya Bagi Pendidikan Agama Kristen"

24 Talizaro Tafonao, "Peran Pendidikan Agama Kristen Dalam Keluarga Terhadap Prilaku Anak," Edudikara: Jurnal Pendidikan Dan Pembelajaran Vol.3, no. No.2 (2018): 129-131.

25 Jarot Wijanarko, Mendidik Anak Dengan Hati, 106-149.

26 Dadan Sumara, Sahadi Humaedi, dan Meilanny Budiarti Santoso, "Kenakalan Remaja dan Penanganannya," Jurnal Penelitian \& PPM 4, no. 2 (2017): 129-389. 
cukup, maka anak akan mudah menemukan sosok figur Tuhan yang dipercayai dalam kehidupannya, karena orang tua dapat menjadi gambaran yang baik tentang sosok Tuhan yang diyakininya. Namun, anak yang dibesarkan dengan tidak adanya rasa kasih sayang di dalam keluarga, akan menghasilkan anak yang tidak percaya terhadap orang tuanya, sehingga anak juga sulit untuk memiliki kepercayaan terhadap Tuhan. ${ }^{27}$ Untuk itu, orang tua perlu memberikan waktu dari segala kesibukannya untuk memberikan rasa kasih sayang yang cukup kepada setiap anaknya, sehingga anak-anak tersebut dapat bertumbuh dengan pertumbuhan Spiritualitas yang baik.

Kelima, membantu menyelesaikan permasalahan remaja generasi Z berdasarkan ajaran iman Kristen. Pada masa kini, remaja generasi Z kerap kali dalam menyelesaikan masalahnya dengan tindakan-tindakan, seperti: melakukan bullying kepada orang yang lebih lemah, suka berkelahi dan tawuran, menggunakan narkoba, minum-minuman keras, bermain game online tanpa batas waktu, tidak suka berbaur, dan lain sebagainya. Hal tersebut terjadi karena kurangnya perhatian dan pengawasan dari para orang tua dalam melihat permasalahan yang terjadi pada anak remaja masa kini, sehingga kerap kali remaja mencari solusi permasahanan yang dihadapinya dengan melakukan tindakan-tindakan yang dapat merugikan dirinya sendiri dan juga orang lain. ${ }^{28}$ Oleh karena itu, para orang tua Kristen perlu untuk mengetahui setiap permasalahan anak remajanya, sehingga para orang tua dapat menuntun, mengarahkan, dan membantu remaja generasi $\mathrm{Z}$ dalam mengambil keputusan yang tepat dan bijak untuk menyelesaikan permasalahan mereka berdasarkan prinsip-prinsip dari ajaran iman Kristen. ${ }^{29}$

Keenam, memberikan disiplin rohani. Remaja generasi $\mathrm{Z}$ sangat akrab dengan dunia digital (internet). Hal tersebut dapat menguntungkan dan dapat juga merugikan bagi remaja. Nurdianto menjelaskan, salah satu dampak yang dapat merugikan remaja sekarang ialah mudahnya remaja menjadi target berita hoax dan ikut menyebarkannya. Selain itu, di zaman sekarang pola konsumtif remaja sudah sangat berlebihan dan tidak seimbang dengan kemandirian ekonomi dari remaja tersebut. ${ }^{30}$ Oleh karena itu, para orang tua Kristen saat ini perlu untuk memberikan disiplin rohani di dalam keluarga, sebagaimana Tuhan memberi ajaran dan aturan untuk mendidik umat-Nya. Demikian halnya dengan orang tua perlu membuat aturan terhadap anak-anaknya agar dapat menggunakan teknologi dengan sebijak mungkin sehingga anak memiliki kedewasaan,

\footnotetext{
27 Ibid.

28 Sumara, Humaedi, dan Santoso, "Kenakalan Remaja dan Penanganannya."

${ }^{29}$ Nova Ritonga et al., "Implementasi Metode Problem Solving dalam Meningkatkan Pembelajaran Pendidikan Agama Kristen di Sekolah,” Jurnal Shanan 5, no. 1 (2021): 29-42.

30 Rizki Fadriani, "Masalah Yang Dihadapi Para Generasi Berencana di Era Digital," tribunpontianak.co.id, last modified 2018, https://pontianak.tribunnews.com/2018/09/25/ini-masalahyang-dihadapi-para-generasi-berencana-di-era-digital.
} 
etika, dan sopan santun yang sesuai dengan ajaran iman Kristen. ${ }^{31}$ Selain itu, dengan adanya disiplin rohani yang dilaksanakan di dalam keluarga, akan menjaga kualitas dari pertumbuhan spiritualitas remaja, karena akan meminimalkan remaja terpengaruh dari penyalahgunaan teknologi, seperti melihat film-film yang tidak layak dan game-game yang dapat merusak pola pikir remaja.

Ketujuh, melibatkan remaja generasi $\mathrm{Z}$ terlibat dalam pelayanan di gereja. Remaja generasi $\mathrm{Z}$ merupakan anak-anak yang memiliki kemampuan multitalenta, khususnya dalam penggunaan teknologi. Untuk itu, orang tua perlu mendukung agar kemampuan yang dimiliki remaja generasi $\mathrm{Z}$ dapat terus dikembangkan dan diimplementasikan dalam lingkungan pelayanan gereja. Misalnya, apabila remaja mempunyai kemampuan dalam mengoperasikan alat-alat teknologi, orang tua dapat melibatkan mereka agar membantu pelayanan multimedia yang ada di gereja supaya semakin maju. Dengan begitu, pertumbuhan spiritualitas remaja juga akan terus terbangun, dikarenakan remaja berada pada dilingkungan (gereja) yang dapat mendukung pertumbuhan spiritualitasnya. Selain itu, dengan adanya dukungan dari para orang tua terhadap remaja generasi $\mathrm{Z}$ dalam mengembangkan kemampuannya, akan membuat mereka semakin semangat dalam melayani Tuhan.

\section{Kesimpulan}

Remaja generasi Z dilahirkan pada era teknologi digital. Salah satu ciri dari remaja generasi $\mathrm{Z}$ ialah mempunyai kemampuan yang baik dalam mengakses informasi melalui media sosial. Selain itu, remaja generasi $\mathrm{Z}$ juga mempunyai konsep berpikir yang berbeda dari generasi-generasi sebelumnya. Hal tersebut dialami oleh remaja generasi $\mathrm{Z}$, karena fasilitas dari perkembangan teknologi yang canggih telah banyak membentuk pola berpikir mereka. Oleh karena itu, remaja generasi $\mathrm{Z}$ sangat membutuhkan pendidikan yang tepat di dalam keluarganya agar mereka tidak salah dalam mengambil keputusan untuk melangkah menjalani kehidupan sehari-harinya.

Di dalam keluarga, orang tua mempunyai peran yang tidak dapat digantikan oleh siapapun dalam mendidik anak-anaknya. Terutama di dalam keluarga Kristen, orang tua perlu mendidik anak-anaknya agar memiliki pertumbuhan spiritualitas yang baik, sehingga setiap anggota keluarga dapat mengimplementasikan kepercayaannya dalam kehidupan sehari-hari yang seturut dengan ajaran iman Kristen. Untuk itu, adapun PAK dalam keluarga yang perlu dilaksanakan oleh orang tua untuk membangun spiritualitas dari remaja generasi Z, antara lain: Pertama, membangun mezbah keluarga. Kedua, membuat target capaian dengan menyesuaikan perkembangan spiritualitas remaja generasi $\mathrm{Z}$ berdasarkan tingkat usianya. Ketiga, mempunyai keteladanan yang baik

\footnotetext{
31 Jarot Wijanarko, Mendidik Anak Dengan Hati (Jakarta: Keluarga Indonesia Bahagia, 2018), 106149.
} 
untuk ditiru. Keempat, ada waktu untuk memberikan kasih sayang. Kelima, membantu menyelesaikan permasalahan remaja generasi $\mathrm{Z}$ berdasarkan ajaran iman Kristen. Keenam, memberikan disiplin rohani. Ketujuh, melibatkan remaja generasi Z dalam pelayanan di gereja.

\section{Referensi}

Ali, Mohammad. Psikologi Remaja Perkembangan Peserta Didik. Jakarta: Bumi Aksara, 2010.

Astuti, Puji. "Bimas Kristen Ungkap 50\% Generasi Milenial Kristen Tinggalkan Gereja, Ini Data Risetnya!” Jawaban.com. Last modified 2019. Diakses Mei 22, 2020. https://www.jawaban.com/read/article/id/2019/07/10/91/190710154206/bim as_kristen_ungkap_50generasi_milenial_kristen_tinggalkan_gerejaini_data_risetnya.

Ermayani, Tri. "Pembentukan Karakter Remaja melalui Keterampilan Hidup." Jurnal Pendidikan Karakter 5, no. 2 (2015): 127-141.

Fadriani, Rizki. "Masalah Yang Dihadapi Para Generasi Berencana di Era Digital." tribunpontianak $\quad$ co. id. Last modified 2018. https://pontianak.tribunnews.com/2018/09/25/ini-masalah-yang-dihadapi-paragenerasi-berencana-di-era-digital.

Gunadi, Pdt. Dr. Paul. “Anak dan Kemajuan Teknologi.” Telaga. Last modified 2016. Diakses Agustus 12, 2020. https://telaga.org/audio/anak_dan_kemajuan_teknologi.

Hastuti, Ruwi. "Pendidikan Agama Kristen Dalam Keluarga Sebagai Pusat Bermisi." Jurnal Antusias 2, no. 4 (2013): 48-59.

Homrighausen, E.G. dan I.H. Enklaar. Pendidikan Agama Kristen. Jakarta: BPK Gunung Mulia, 2012.

Kristianto, Paulus Lilik. Prinsip dan Praktik Pendidikan Agama Kristen. Yogyakarta: ANDI, 2012.

Mukhlis, Herry. "Pahami Remaja Generasi-Z." AF MAGAZINE. Tanggerang, November 2015. http://alfathschoolindonesia.sch.id/wp-content/uploads/2017/03/PahamiRemaja-Generasi-Z.pdf.

Ngafifi, Muhamad. "Kemajuan Teknologi dan Pola Hidup Manusia dalam Perspektif Sosial Budaya." Jurnal Pembangunan Pendidikan: Fondasi dan Aplikasi 2, no. 1 (2014): 38.

Prihatana, BR. Agung. Pendidikan Iman Anak dalam Keluarga Kawin Campur Beda Agama. Yogyakarta: Kanisius, 2007.

Primasari, Dwi Ammelia Galuh, Dencik Dencik, and M. Imansyah. "Pendidikan Karakter Bagi Generasi Masa Kini." Prosiding Seminar Nasional Program Pascasarjana Universitas PGRI Palembang 12, no. 1 (2019): 1100-1118. https://jurnal.univpgri- 
palembang.ac.id/index.php/Prosidingpps/article/view/2672.

Ritonga, Nova, Juliandes Leonardo Trisno Mone, Mathan Yunip, dan Yunardi Kristian Zega. "Implementasi Metode Problem Solving dalam Meningkatkan Pembelajaran Pendidikan Agama Kristen di Sekolah." Jurnal Shanan 5, no. 1 (2021): 29-42.

Sahartian, Santy. "Pengaruh Pembinaan Rohani Keluarga Terhadap Karakter Pemuda Berdasarkan Kolose 2: 6-10 Di GBAP Surakarta." FIDEI: Jurnal Teologi Sistematika dan Praktika 2, no. 1 (Juni 18, 2019): 20-39. http://www.stt-tawangmangu.ac.id/ejournal/index.php/fidei/article/view/30.

Sianipar, Desi, Yunardi Kristian Zega, Luterius Nehe, dan Kristiantoro. "Pelatihan Penyusunan Kurikulum Pendidikan Agama Kristen Remaja di HKBP Jatisampurna Bekasi." JURNAL ComunitÃ Servizio : Jurnal Terkait Kegiatan Pengabdian kepada Masyarakat, terkhusus bidang Teknologi, Kewirausahaan dan Sosial Kemasyarakatan 2, no. 2 (November 2, 2020): 447-457. http://ejournal.uki.ac.id/index.php/cs/article/view/1964.

Sihombing, Riana Udurman, dan Rahel Rati Sarungallo. "Peranan Orang Tua Dalam Mendewasakan Iman Keluarga Kristen." Journal Kerusso 4, no. 1 (Maret 19, 2019): 34-41. http://jurnal.sttii-surabaya.ac.id/index.php/Kerusso/article/view/104.

Sumara, Dadan, Sahadi Humaedi, dan Meilanny Budiarti Santoso. "Kenakalan Remaja dan Penanganannya." Jurnal Penelitian \& PPM 4, no. 2 (2017): 129-389.

Susanti, Susi. "Gaya Hidup Pemuda Kristen Terhadap Perkembangan Teknologi (Media Sosial)." OSF. Last modified 2020. Diakses Agustus 13, 2020. https://osf.io/zrt6u/.

Tafonao, Talizaro. "Peran Pendidikan Agama Kristen dalam Keluarga Terhadap Prilaku Anak." Edudikara: Jurnal Pendidikan dan Pembelajaran Vol.3, no. No.2 (2018): 129131.

Wijanarko, Jarot. Mendidik Anak dengan Hati. Jakarta: Keluarga Indonesia Bahagia, 2018.

Zega, Yunardi Kristian. “Teori Perkembangan Iman Remaja Menurut James W. Fowler dan Implikasinya Bagi Pendidikan Agama Kristen." Jurnal Pendidikan dan Kebudayaan Missio 12, no. 2 (Juli 6, 2020): 140-151. http://unikastpaulus.ac.id/jurnal/index.php/jpkm/article/view/488. 